\title{
Detection of Methane Emission from a Local Source Using GOSAT Target Observations
}

\author{
Akihiko Kuze ${ }^{1, *} \mathbb{1}$, Nobuhiro Kikuchi ${ }^{1}$, Fumie Kataoka ${ }^{2}{ }^{\oplus}$, Hiroshi Suto ${ }^{1}$, Kei Shiomi ${ }^{1}(\mathbb{D}$ \\ and Yutaka Kondo ${ }^{3}$ \\ 1 Japan Aerospace Exploration Agency, Tsukuba-City, Ibaraki 305-8505, Japan; \\ kikuchi.nobuhiro@jaxa.jp (N.K.); suto.hiroshi@jaxa.jp (H.S.); shiomi.kei@jaxa.jp (K.S.) \\ 2 Remote Sensing Technology Center of Japan, Tsukuba-City, Ibaraki 305-8505, Japan; \\ kataoka.fumie@restec.or.jp \\ 3 National Institute of Polar Research, Tachikawa-City 190-8518, Japan; kondo.yutaka@nipr.ac.jp \\ * Correspondence: kuze.akihiko@jaxa.jp; Tel.: +81-50-3362-2505
}

Received: 14 November 2019; Accepted: 6 January 2020; Published: 13 January 2020

\begin{abstract}
Emissions of atmospheric methane $\left(\mathrm{CH}_{4}\right)$, which greatly contributes to radiative forcing, have larger uncertainties than those for carbon dioxide $\left(\mathrm{CO}_{2}\right)$. The Thermal And Near-infrared Sensor for carbon Observation Fourier-Transform Spectrometer (TANSO-FTS) onboard the Greenhouse gases Observing SATellite (GOSAT) launched in 2009 has demonstrated global grid observations of the total column density of $\mathrm{CO}_{2}$ and $\mathrm{CH}_{4}$ from space, and thus reduced uncertainty in the global flux estimation. In this paper, we present a case study on local $\mathrm{CH}_{4}$ emission detection from a single-point source using an available series of GOSAT data. By modifying the grid observation pattern, the pointing mechanism of TANSO-FTS targets a natural gas leak point at Aliso Canyon in Southern California, where the clear-sky frequency is high. To enhance local emission estimates, we retrieved $\mathrm{CO}_{2}$ and $\mathrm{CH}_{4}$ partial column-averaged dry-air mole fractions of the lower troposphere $\left(\mathrm{XCO}_{2}(\mathrm{LT})\right.$ and $\left.\mathrm{XCH}_{4}(\mathrm{LT})\right)$ by simultaneous use of both sunlight reflected from Earth's surface and thermal emissions from the atmosphere. The time-series data of Aliso Canyon showed a large enhancement that decreased with time after its initial blowout, compared with reference point data and filtered with wind direction simulated by the Weather Research and Forecasting (WRF) model.
\end{abstract}

Keywords: GOSAT; methane; partial column density; SWIR; TIR; gas leak; WRF; flux

\section{Introduction}

Among trace gases in the atmosphere, methane $\left(\mathrm{CH}_{4}\right)$ contributes significantly to radiative forcing, second only to carbon dioxide $\left(\mathrm{CO}_{2}\right)$, although its emissions estimates have larger uncertainties than those of $\mathrm{CO}_{2}$. Major anthropogenic source sectors are oil/gas production, coal mining, livestock, landfills, wastewater, and rice cultivation. A better understanding of the distribution and amount of emissions contributes to effective reductions in $\mathrm{CH}_{4}$ emissions. In situ measurements taken on the ground or by aircraft, using such instruments as cavity-ringdown spectrometers, have high accuracy and precision, but the number of observation points is limited. Airborne remote sensing has demonstrated $\mathrm{CH}_{4}$ point-source emissions and their plumes using imaging capabilities [1-3]. With its high spatial resolution, these measurements can detect the fine horizontal structure of plumes from individual emission source, but these are temporary. Long-term measurements are needed for more systematic estimates of $\mathrm{CH}_{4}$ emissions. Satellite observations can provide global $\mathrm{CH}_{4}$ data in a long time-series (over a decade) to investigate anthropogenic $\mathrm{CH}_{4}$ emissions. Compared to the wide-spread urban $\mathrm{CO}_{2}$ emissions, such as those from transportation, most anthropogenic $\mathrm{CH}_{4}$ source areas are smaller than a single pixel in satellite footprints. Such areas can be treated as point sources for existing 
satellite observations. Jacob et al. [4] reviewed the value of present, future, and proposed satellite observations to better quantify and understand $\mathrm{CH}_{4}$ emissions through inverse analyses from the global scale down to the scale of point sources.

The Scanning Imaging Absorption Spectrometer for Atmospheric CHartographY (SCIAMACHY) is the first spectrometer to observe both $\mathrm{CO}_{2}$ and $\mathrm{CH}_{4}$ form space [5]. After its operation in April 2012 and prior to the launch of the Orbiting Carbon Observatory-2 (OCO-2) for $\mathrm{CO}_{2}$ in 2014, TanSAT for $\mathrm{CO}_{2}$ in 2015, GHGSat for $\mathrm{CH}_{4}$ in 2016, TROPOspheric Monitoring Instrument (TROPOMI) onboard the Sentinel-5 Precursor satellite for $\mathrm{CH}_{4}$ in 2017, and OCO-3 onboard International Space Station (ISS) for $\mathrm{CO}_{2}$ in 2019, the Greenhouse gases Observing SATellite (GOSAT) was the only instrument that could provide $\mathrm{CO}_{2}$ and $\mathrm{CH}_{4}$ column amounts, which are sensitive to the surface from space [6-12]. GOSAT has demonstrated global grid observation of total column density of $\mathrm{CO}_{2}$ and $\mathrm{CH}_{4}$ from space, and thus has reduced the uncertainty in global flux estimation.

Missions with high spectral resolution for measuring thermal emission include the Atmospheric Infrared Sounder (AIRS) onboard the Earth Observing System (EOS) PM spacecraft, the Tropospheric Emission Spectrometer (TES) onboard the EOS Aura, the Infrared Atmospheric Sounding Interferometer (IASI) onboard Metop satellite, and the Cross-track Infrared Sounder (CrIS) onboard the Suomi National Polar-orbiting Partnership Project (SNPP). They can provide vertical profile information but do not have sufficient sensitivity for enhancements near the surface [13-16].

As summarized in Table 1, GOSAT is the only nadir-viewing mission that can observe reflected and scattered solar light with two linear polarizations and thermal emission simultaneously. An individual linear polarization band include information on highly polarized scattering by particles. By providing long-term high-resolution spectral data, TANSO-FTS is a pathfinder for subsequent missions and it also provides information to better understand radiative transfer.

Table 1. Nadir-viewing space-borne missions.

\begin{tabular}{|c|c|c|c|c|c|c|c|}
\hline & \multirow{2}{*}{$\begin{array}{l}\text { Operation } \\
\text { (Year) }\end{array}$} & \multicolumn{2}{|c|}{ Target } & \multirow{2}{*}{ Reflected Solar Light } & \multirow{2}{*}{ Thermal Emission } & \multirow{2}{*}{ Pointing } & \multirow{2}{*}{ Footprint } \\
\hline & & $\mathrm{CO}_{2}$ & $\mathrm{CH}_{4}$ & & & & \\
\hline \multicolumn{2}{|c|}{ SCIAMACHY 2002-2012 } & $\checkmark$ & $\checkmark$ & $\checkmark$ & & & Entire surface \\
\hline GOSAT & 2009-now & $\checkmark$ & $\checkmark$ & $\checkmark$ & $\checkmark$ & $\checkmark$ & Sparse \\
\hline OCO-2 & 2014-now & $\checkmark$ & & $\checkmark$ & & & Sparse \\
\hline TanSAT & 2015-now & $\checkmark$ & & $\checkmark$ & & & Sparse \\
\hline GHGSat & 2016-now & & $\checkmark$ & $\checkmark$ & & $\checkmark$ & Sparse \\
\hline TROPOMI & 2017-now & & $\checkmark$ & $\checkmark$ & & & Entire surface \\
\hline OCO-3 & 2019-now & $\checkmark$ & & $\checkmark$ & & $\checkmark$ & Sparse \\
\hline AIRS & 2002-now & $\checkmark$ & $\checkmark$ & & $\checkmark$ & & Entire surface \\
\hline TES & 2004-now & & $\checkmark$ & & $\checkmark$ & & Sparse \\
\hline IASI & 2006-now & & $\checkmark$ & & $\checkmark$ & & Entire surface \\
\hline CrIS & 2011-now & & $\checkmark$ & & $\checkmark$ & & Entire surface \\
\hline
\end{tabular}

However, the grid scan mode covers only $0.1 \%$ of Earth's surface and has missed most $\mathrm{CH}_{4}$ point sources. Turner et al. and Sheng et al. estimated $\mathrm{CH}_{4}$ emissions from North America from different source sectors from sparse sampling data $[17,18]$. To capture all $\mathrm{CH}_{4}$ emissions, the satellite footprint must cover the point source area. In this study, we modified the pointing pattern locally and retrieved the columnar densities of lower troposphere (LT) $\mathrm{CH}_{4}$ and $\mathrm{CO}_{2}$ by simultaneous use of reflected shortwave-infrared (SWIR) solar light and thermal infrared (TIR) emissions. This paper describes how a local $\mathrm{CH}_{4}$ emission could be detected using existing GOSAT functionalities and wind simulation. We also discuss the possible causes of uncertainty in the local flux estimates and suggest possibilities that might reduce such uncertainties using imaging capabilities on the local flux estimate through satellite data. 


\section{Data Acquisition and Analytical Dataset for Local Emission Detection}

\subsection{GOSAT Observations}

GOSAT carries the Thermal And Near-infrared Sensor for carbon Observation Fourier-Transform Spectrometer (TANSO-FTS), which simultaneously observes both reflected SWIR solar light and TIR emissions with a single FTS mechanism. Table 2 lists the principal specifications of the GOSAT orbit and the TANSO-FTS spectral band. As described in Table 3, it measures narrow spectral bands at $0.76 \mu \mathrm{m}$ for oxygen $\left(\mathrm{O}_{2}\right), 1.6 \mu \mathrm{m}$ for $\mathrm{CO}_{2}$ and $\mathrm{CH}_{4}$, and $2.0 \mu \mathrm{m}$ for $\mathrm{CO}_{2}$, with a spectral sampling interval of $0.2 \mathrm{~cm}^{-1}$. It also has a wide spectral band to measure thermal emissions from Earth's surface and atmosphere, including $\mathrm{CO}_{2}$ and $\mathrm{CH}_{4}$. The reflected SWIR solar light passes through Earth's troposphere, reflects over the surface, and then returns to space. The $\mathrm{O}_{2} A$ band at $0.76 \mu \mathrm{m}$ provides the surface pressure $\left(\mathrm{P}_{\text {surf }}\right)$. Two linear polarization bands provide information on light-path modification and make accurate remote sensing possible, even under aerosol and thin-cloud contaminated conditions. To maximize the optical throughput of FTS, GOSAT has a circular instantaneous field of view (IFOV) of $15.8 \mathrm{mrad}$ to collect enough photons to improve the signal-to-noise ratio (SNR). The footprint is $10.5 \mathrm{~km}$ in diameter for nadir observations.

Table 2. Principal specifications of the GOSAT orbit and the TANSO-FTS instrument.

\begin{tabular}{ccc}
\hline Type of Orbit & \multicolumn{2}{c}{ Sun-Synchronized Sub-Recurrent Orbit } \\
\hline Altitude of Orbit & $666 \pm 0.6 \mathrm{~km}$ \\
Local solar time & $13: 00 \pm 15 \mathrm{~min}$ & \\
Pointing mechanism & Cross track & $\pm 35^{\circ}$ \\
& Along track: & $\pm 20^{\circ}$ \\
& Type of interferometer & Double pendulum \\
Spectrometer & Maximum optical path difference & $\pm 2.5 \mathrm{~cm}$ (both sides) \\
& Aperture & $68 \mathrm{~mm}$ \\
Interferogram acquisition & Scan speed (one way) & 4 s/Interferogram \\
Instantaneous field of view & Both directions (forward and reverse scans) \\
\hline
\end{tabular}

Table 3. Specifications of spectral bands.

\begin{tabular}{ccccc}
\hline & Band 1 & Band 2 & Band 3 & Band 4 \\
\hline $\begin{array}{c}\text { Spectral range }\left(\mathrm{cm}^{-1}\right) \\
\text { Number of Linear } \\
\text { polarization bands }\end{array}$ & $12,900-13,200$ & $5800-6400$ & $4800-5200$ & $700-1800$ \\
$\begin{array}{c}\text { Spectral resolution for P } \\
\text { polarization }\left(\mathrm{cm}^{-1}\right)^{*}\end{array}$ & 0.367 & 0.258 & 2 & N/A \\
$\begin{array}{c}\text { Spectral resolution for S } \\
\text { polarization }\left(\mathrm{cm}^{-1}\right)^{*}\end{array}$ & 0.356 & 0.257 & 0.262 & N/A \\
$\begin{array}{c}\text { Sampling interval }\left(\mathrm{cm}^{-1}\right) \\
\text { Detector }\end{array}$ & $\mathrm{Si}$ & InGaAs & InGaAs & N/A \\
\hline
\end{tabular}

* The spectral resolution is defined as full width at half maximum (FWHM) of the measured instrument line shape function (ILSF) before launch.

\subsection{Targeting Point Sources}

TANSO-FTS has a two-axis agile pointing system, which allows cross-track (CT) and along-track (AT) motions of $\pm 35^{\circ}$ and $\pm 20^{\circ}$, respectively, and compensates for the satellite image-motion during interferogram acquisition. It was originally designed for grid scan observations and viewing onboard calibration sources. It takes $4 \mathrm{~s}$ to acquire a single interferogram and $0.6 \mathrm{~s}$ for pointing and turnaround of the FTS mechanism. For the first six years of GOSAT operations, TANSO-FTS operated mainly in three-point $\mathrm{CT}$ scan mode to monitor global $\mathrm{CO}_{2}$ and $\mathrm{CH}_{4}$ with a three-day revisit cycle, using the primary part of the redundant pointing systems with a grid of about $300 \mathrm{~km}$. After the pointing 
mechanism was switched from primary to secondary on 26 January 2015, the pointing showed more accurate geolocation and stable settling than the degraded primary system. We decided to make more frequent target observations, by uploading AT and CT pointing angles and observation timing as commands from the ground every day [12]. The pointing bias and its fluctuations have generally been smaller than $0.1^{\circ}$, corresponding to a $1 \mathrm{~km}$ surface footprint bias or fluctuations. When a sufficiently strong point source is located within the $10.5 \mathrm{~km}$ footprint in nadir, GOSAT can capture total $\mathrm{CH}_{4}$ emissions that spread horizontally and vertically. Over the three-day revisit cycle, data of 56,000 locations are acquired, most of which are grid observations and onboard calibrations. About 1000 locations are allocated to target observations, such as the Total Carbon Column Observing Network (TCCON) validation sites, desert areas for radiometric calibration, megacities, or large emission sources $[12,19]$.

\subsection{Derivation of $\mathrm{CH}_{4}$ Partial Column-averaged Density in the Lower Troposphere}

Estimation of the $\mathrm{CH}_{4}$ local emission requires the columnar density of the $\mathrm{LT}_{\mathrm{CH}}$ in order to enhance near-surface density and reduce the inflow in the upper atmosphere. Existing GOSAT Level 2 products have provided the column-averaged dry-air mole fractions of $\mathrm{CO}_{2}$ and $\mathrm{CH}_{4}\left(\mathrm{XCO}_{2}\right.$ and $\mathrm{XCH}_{4}$, respectively), but only from the three SWIR-band data [20-25]. The standard deviation of $\mathrm{XCO}_{2}$ and $\mathrm{XCH}_{4}$ are $2.1 \mathrm{ppm}$ or $0.5 \%$ and $13 \mathrm{ppb}$ or $0.7 \%$, respectively, compared with the TCCON data. Their biases are $-1.48 \mathrm{ppm}$ and $-5.9 \mathrm{ppb}$ for $\mathrm{XCO}_{2}$ and $\mathrm{XCH}_{4}$, respectively. Columnar $\mathrm{CH}_{4}$ density is the average value of the LT, upper troposphere (UT), and the stratosphere. Therefore, it is influenced by inflows of $\mathrm{CH}_{4}$ in the UT and the stratosphere from a much wider area. In estimating $\mathrm{CH}_{4}$ emissions from a local point source, it is highly desirable to extract columnar density only of the $\mathrm{LT} \mathrm{CH}_{4}$. TIR spectra emitted from $\mathrm{CO}_{2}$ and $\mathrm{CH}_{4}$ contain vertical profile information, due to the temperature gradient. Conventional algorithms for the TIR band have attempted to acquire $\mathrm{CO}_{2}$ and $\mathrm{CH}_{4}$ densities for ten vertical layers in the troposphere, resulting in unstable retrievals due to the uncertainties of radiometric calibrations [26]. In addition, TIR data alone do not contain enough information of near-surface $\mathrm{CO}_{2}$ and $\mathrm{CH}_{4}$, and thus are inadequate for local emission analysis.

We reduced the number of vertical layers for a more robust retrieval $[27,28]$. We can retrieve the difference between the partial column-averaged dry-air mole fractions of the two individual layers of LT and UT $\left(\mathrm{XCO}_{2}(\mathrm{LT}), \mathrm{XCO}_{2}(\mathrm{UT}), \mathrm{XCH}_{4}(\mathrm{LT})\right.$, and $\left.\mathrm{XCH}_{4}(\mathrm{UT})\right)$ by combining TIR and SWIR spectra data simultaneously, thereby constraining the accurate total column density of $\mathrm{XCO}_{2}$ and $\mathrm{XCH}_{4}$.

We retrieved five vertical layers: two in the troposphere and three in the stratosphere. We used the entire spectral range acquired with the FTS listed in Table 3 including absorption bands of $\mathrm{O}_{2} A$ at $0.76 \mu \mathrm{m}, \mathrm{CO}_{2}$ and $\mathrm{CH}_{4}$ at $1.6 \mu \mathrm{m}$, and $\mathrm{CO}_{2}$ at $2.0 \mu \mathrm{m}$, and thermal emission from atmospheric $\mathrm{CO}_{2}$ and $\mathrm{CH}_{4}$. The simultaneous use of two liner polarizations can provide accurate light-path modification under thick aerosol conditions.

The retrieval method is the maximum a posteriori solution found by minimizing a cost function. For reflected solar light, we used the vector equation of radiative transfer for the diffuse components of the Stokes parameters. We define vertical layers of LT and UT not by temperature, but by the retrieved $\mathrm{P}_{\text {surf }}$ from individual $\mathrm{O}_{2} A$ band data as retrieved vertical temperature has a larger uncertainty. The pressure-height ranges of the LT and UT were taken as 0.6-1 $\mathrm{P}_{\text {surf }}$ and $0.2-0.6 \mathrm{P}_{\text {surf }}$, respectively. Both LT and UT have the same air masses. The exact ranges of each vertical layer were determined by individually retrieved $\mathrm{P}_{\text {surf. }}$. In the case of ocean data, the vertical range of LT becomes $0-4 \mathrm{~km}$. We allocate three layers in the stratosphere to stabilize the retrieval. Most pieces of information on the stratosphere come from a priori data. The typical degrees of freedom for the signal (DFS) are roughly 1.8 for $\mathrm{XCH}_{4}$ (the total column) and 0.8 for $\mathrm{XCH}_{4}$ (LT). Therefore, most of the lower troposphere data are acquired from GOSAT observations. As the LT includes the entire boundary layer, analysis using $\mathrm{XCO}_{2}$ (LT) and $\mathrm{XCH}_{4}$ (LT) can double the signal of local emissions and remove the effects of $\mathrm{CO}_{2}$ and $\mathrm{CH}_{4}$ variability in the UT, which typically extends over a much wider area. We validated our $\mathrm{XCO}_{2}$ (LT) and $\mathrm{XCH}_{4}$ (LT) retrieval algorithm by coincident spiral flights with an airborne spectrometer 
during the annual calibration and validation campaigns at Railroad Valley in Nevada, USA [29-32]. The airplane carried the PICARRO cavity-ringdown spectrometer and measured vertical profiles of in-situ $\mathrm{CO}_{2}$ and $\mathrm{CH}_{4}$ density from the surface to $8 \mathrm{~km}$. For this analysis, we used the Level $1 \mathrm{~B}$ radiance spectra of version 210 to produce $\mathrm{XCO}_{2}(\mathrm{LT}), \mathrm{XCO}_{2}(\mathrm{UT}), \mathrm{XCH}_{4}(\mathrm{LT})$, and $\mathrm{XCH}_{4}(\mathrm{UT})$ [33].

\section{Detectivity Study for Detecting Local Emission}

\subsection{Detectivity and Site Selection}

For a detectivity study, the $\mathrm{CH}_{4}$ flux emitted from a point source using GOSAT target observation is modeled by Equation (1).

$$
\mathrm{F}_{\mathrm{CH}_{4}}=\frac{\mathrm{Va}_{\mathrm{p}}}{\mathrm{L}_{\mathrm{s}}} \Delta \mathrm{XCH}_{4}(\mathrm{LT})=\frac{\mathrm{Va}_{\mathrm{p}}}{\mathrm{L}_{\mathrm{s}}}\left(\mathrm{XCH}_{4}(\mathrm{LT})_{\mathrm{s}}-\mathrm{XCH}_{4}(\mathrm{LT})_{\mathrm{b}}\right)
$$

where $\mathrm{F}_{\mathrm{CH}_{4}}, \mathrm{a}_{\mathrm{p}}, \mathrm{V}$, and $\Delta \mathrm{XCH}_{4}(\mathrm{LT})$ denote $\mathrm{CH}_{4}$ local flux, the partial air mass of the LT within the GOSAT footprint, wind speed in the boundary layer, and enhancement by emissions, respectively; $\mathrm{L}_{\mathrm{s}}$ is the average cross-wind length, which is the average distance between the source location and edge of the GOSAT footprint; and the suffixes $\mathrm{s}$ and $\mathrm{b}$ denote source and background. We assume that $\mathrm{CH}_{4}$ emitted from a point source remains in the LT from the overpass time until the plume reaches the edge of the footprint. Considering the uncertainty of $13 \mathrm{ppb}$ in $\mathrm{XCH}_{4}(\mathrm{LT})_{\mathrm{s}}$ and $\mathrm{XCH}_{4}(\mathrm{LT})_{\mathrm{b}}$ and the footprint area of $87 \mathrm{~km}^{2}$ in Equation (1), the local flux must be larger than the uncertainty level of 5.0 tons of $\mathrm{CH}_{4}$ per hour in the case of $\mathrm{V}=2 \mathrm{~m} / \mathrm{s}$ to be detected by GOSAT. In our case study for demonstrating the observation capability of GOSAT for monitoring large emission trends, we selected Southern California, USA, where clear skies are frequent. The largest emission in the EDGAR grid database in Southern California is lower than 10.0 tons of $\mathrm{CH}_{4}$ per hour, which is close to the level of uncertainty. For a case study, we need a significantly higher emission, thus we selected the natural gas leak at Aliso Canyon (Figure 1a), a blowout event. According to the company's measurements, a gas leak over three months amounted to the emission of at least $97 \mathrm{Gg}$ of $\mathrm{CH}_{4}$, which gives an average emission rate of 45 tons of $\mathrm{CH}_{4}$ per hour [34]. GOSAT can view Aliso Canyon from east-orbit path 36 on the first day of the three-day revisit and from west-orbit path 37 on the following day. Considering that TANSO-FTS needs $4.6 \mathrm{~s}$ to acquire a single datum and has a ground speed of $6.9 \mathrm{~km} / \mathrm{s}$, we can allocate four target observations for each of paths 36 and 37. After the blowout from natural gas storage was reported on 23 October 2015 [35], GOSAT started observing the target twice every three days.

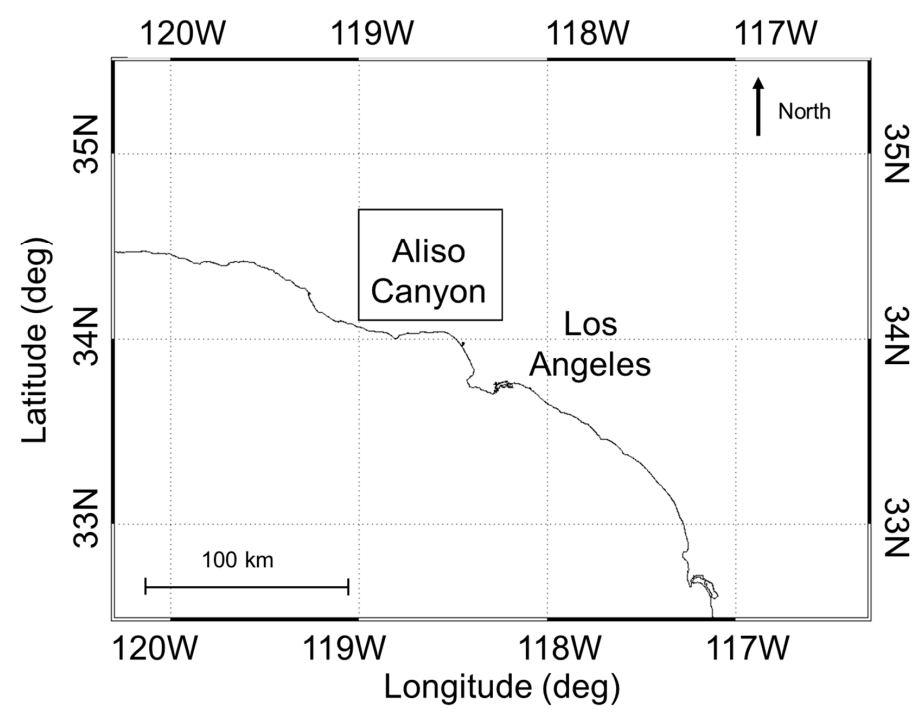

(a)

Figure 1. Cont. 


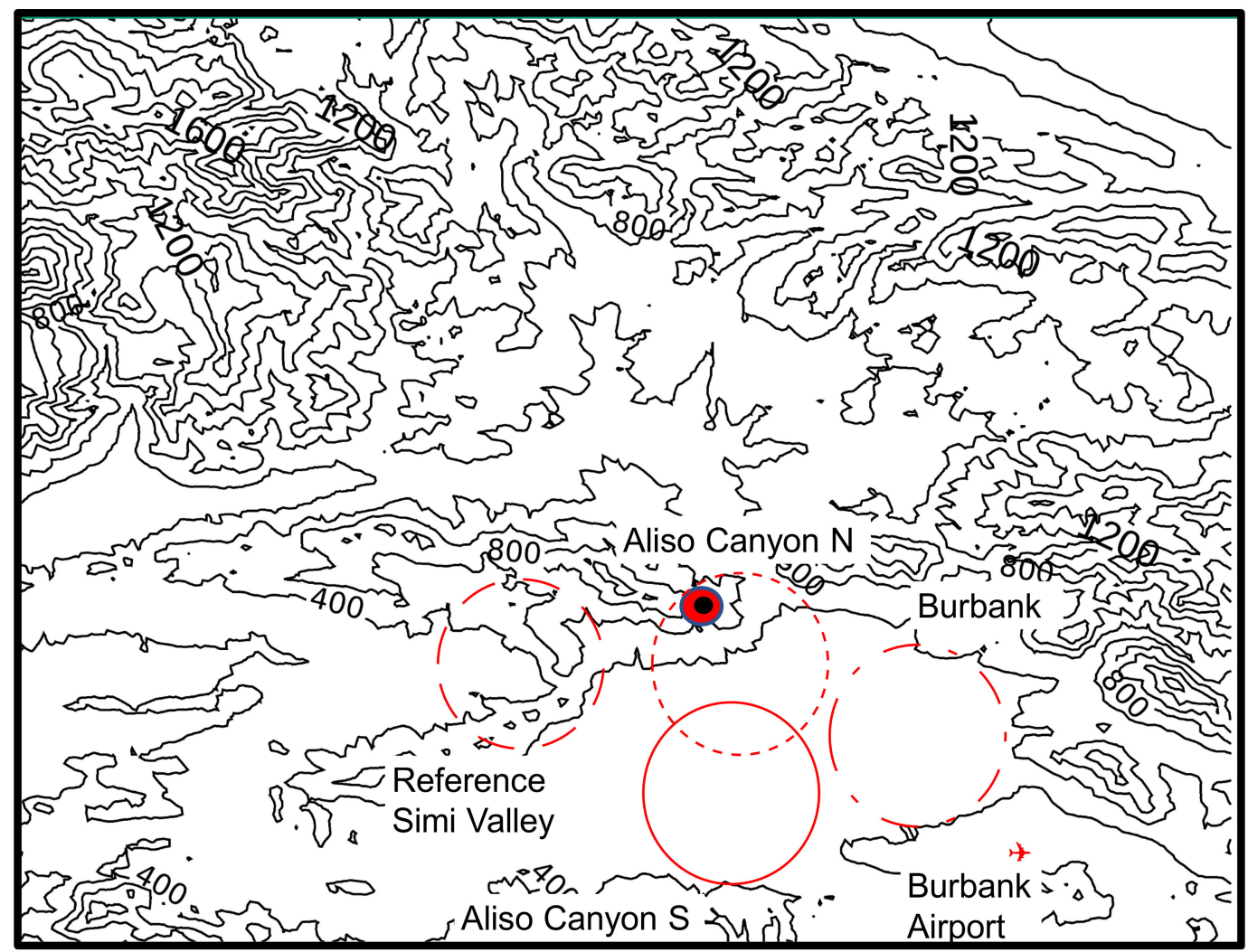

(b)

Figure 1. (a) Aliso Canyon location; and (b) geometric relationship between the leak point and the Greenhouse gases Observing SATellite (GOSAT) footprints (circles) in Simi Valley (dashed line), Aliso Canyon-N (dotted line), Aliso Canyon-S (bold line), and Burbank (dash-dotted line).

\subsection{Trend Analysis for the Gas Leak in Aliso Canyon}

Figure $1 \mathrm{~b}$ illustrates the geometric relation between the point-source location and the footprints of the GOSAT target observations: Simi Valley, located in the basin west of the leak point, was designated as the reference point; Aliso Canyon-N, which includes the leak point, where the topography of the footprint is uneven; Aliso Canyon-S, which is located just south of the leak point and has a flat topography; and Burbank, in the same basin, where the wind observation point at Burbank Airport is located near the GOSAT footprint [36]. The center of the footprints of Simi Valley, Aliso Canyon-N, Aliso Canyon-S, and Burbank are $\left(34.28^{\circ} \mathrm{N}, 118.69^{\circ} \mathrm{W}\right),\left(34.28^{\circ} \mathrm{N}, 118.53^{\circ} \mathrm{W}\right),\left(34.21^{\circ} \mathrm{N}, 118.54^{\circ} \mathrm{W}\right)$, and $\left(34.26^{\circ} \mathrm{N}, 118.44^{\circ} \mathrm{W}\right)$, respectively. All four sites are located to the south of the Transverse Range. Thompson et al. [1] indicated that the wind direction over the leak point changed frequently. For a north wind, the downwind plume entered the GOSAT footprint of Aliso Canyon-S.

Figure 2a,b shows observed $\mathrm{XCH}_{4}$ and $\mathrm{XCH}_{4}$ (LT) and their DFS in retrieval. The LT data showed enhancement soon after the blowout event in 2015, which is much clearer than total column data. DFS values close to 1 demonstrate information content in the observed $\mathrm{XCH}_{4}$ (LT). Figure 3 shows the retrieved $\mathrm{XCH}_{4}(\mathrm{LT})$ and $\mathrm{XCH}_{4}(\mathrm{UT})$ at Aliso Canyon-S. The UT data did not indicate effect by the blowout event. Year-long data for both $\mathrm{XCH}_{4}(\mathrm{LT})$ and $\mathrm{XCH}_{4}$ (UT) showed decreases in summer, whereas, in the other seasons, the data largely fluctuated. Figure 3 shows $\mathrm{XCH}_{4}(\mathrm{UT})$ data that are higher than those of $\mathrm{XCH}_{4}$ (LT). The possible cause is an inflow from other $\mathrm{CH}_{4}$ emission sources. There are several $\mathrm{CH}_{4}$ emission sources such as oil fields and dairy farms in California. We selected pairs of successfully retrieved data at Simi Valley as a reference to $\mathrm{XCH}_{4}$ (LT) at Aliso Canyon-S under clear-sky conditions. The detailed processes of background subtraction, normalization, and filtering are described in the Appendix A. Figure A1 shows the $\mathrm{XCH}_{4}$ (LT) enhancement from Simi Valley at: 
(a) Aliso Canyon-S; and (b) Aliso Canyon-N and Burbank after background subtraction. Figure A2 shows a reduction in the positive bias after normalization. Figure A3 shows the $\mathrm{XCH}_{4}(\mathrm{LT}) / \mathrm{XCO} 2(\mathrm{LT})$ ratio and the WRF wind direction at the leak point during GOSAT overpass for filtering. $\mathrm{XCH}_{4}(\mathrm{LT})$ data for both Simi Valley and Aliso Canyon-N/-S were possibly influenced by pollution inflow from the greater Los Angeles area. The measured $\mathrm{XCH}_{4}(\mathrm{LT})$ at these locations varied significantly, depending on wind conditions, resulting in large fluctuations. We assumed that: (1) urban pollution caused both $\mathrm{CH}_{4}$ and $\mathrm{CO}_{2}$ enhancements; (2) inflow to the reference point of Simi Valley and to Aliso Canyon had the same $\mathrm{CH}_{4}$ to $\mathrm{CO}_{2}$ ratios; and (3) no $\mathrm{CO}_{2}$ was emitted at the gas leak point on the hills of Aliso Canyon. $\mathrm{XCH}_{4}(\mathrm{LT})$ normalized by the retrieved $\mathrm{XCO}_{2}$ (LT) should remove the inflow portion inside the footprint.

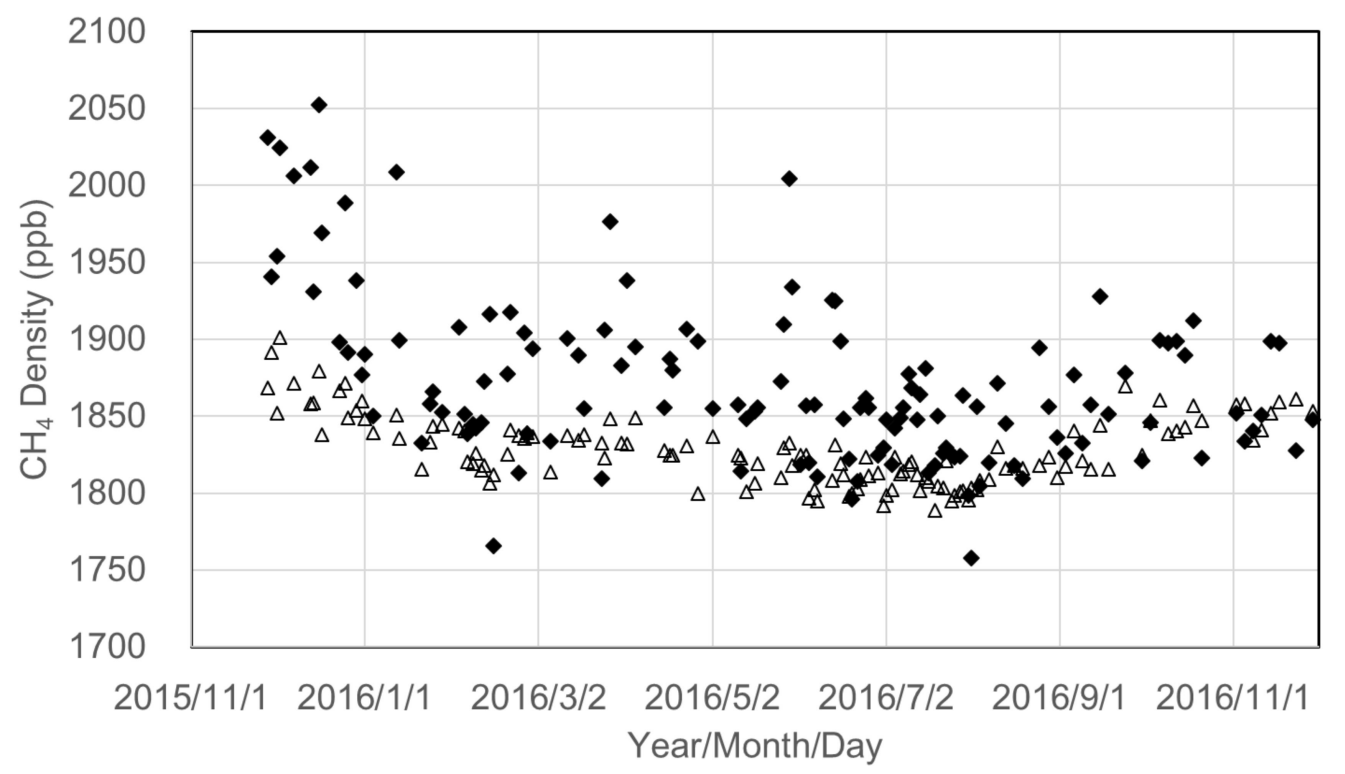

(a)

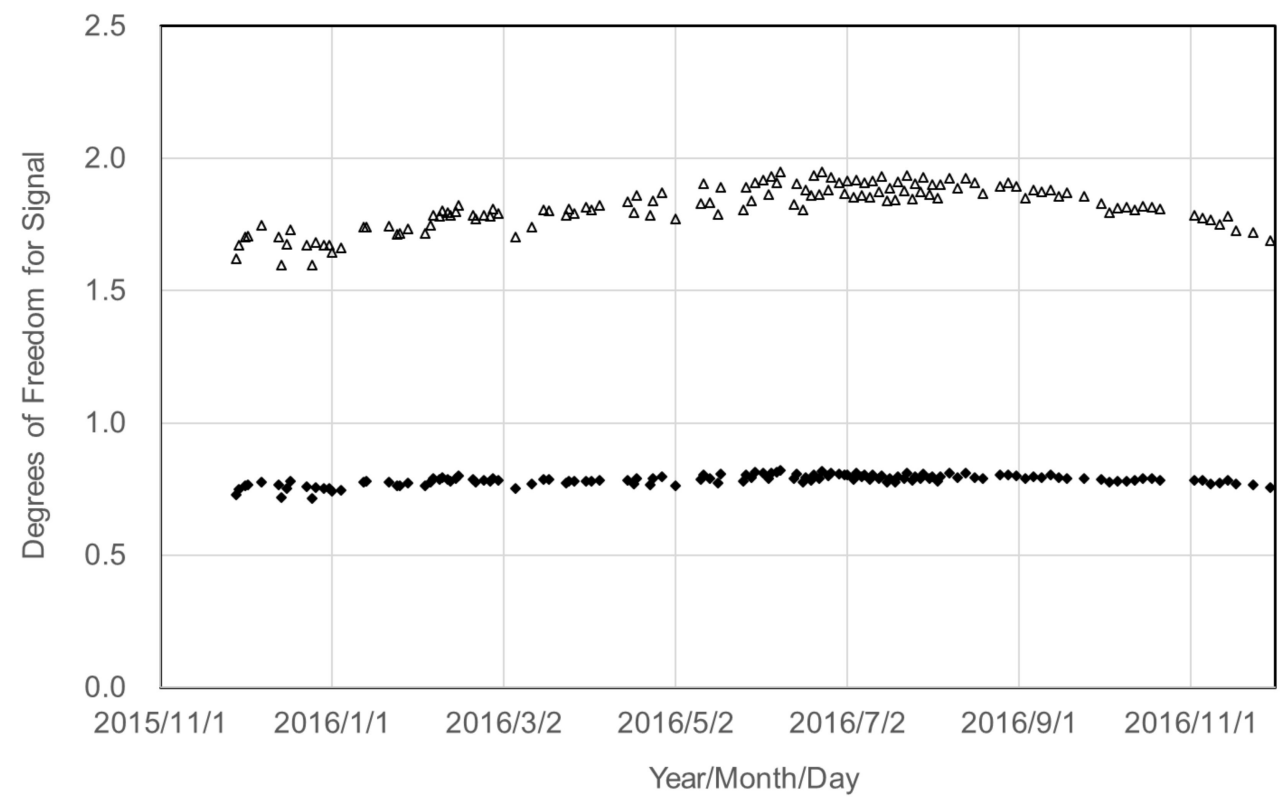

(b)

Figure 2. (a) $\mathrm{CH}_{4}$ total partial column-averaged dry-air mole fractions $\left(\mathrm{XCH}_{4}\right)$ (triangles) and the lower troposphere $\left(\mathrm{XCH}_{4}(\mathrm{LT})\right)$ (diamonds) at Aliso Canyon-S; and (b) the same as (a) except for the typical degrees of freedom for the signal (DFS) in retrieval. 


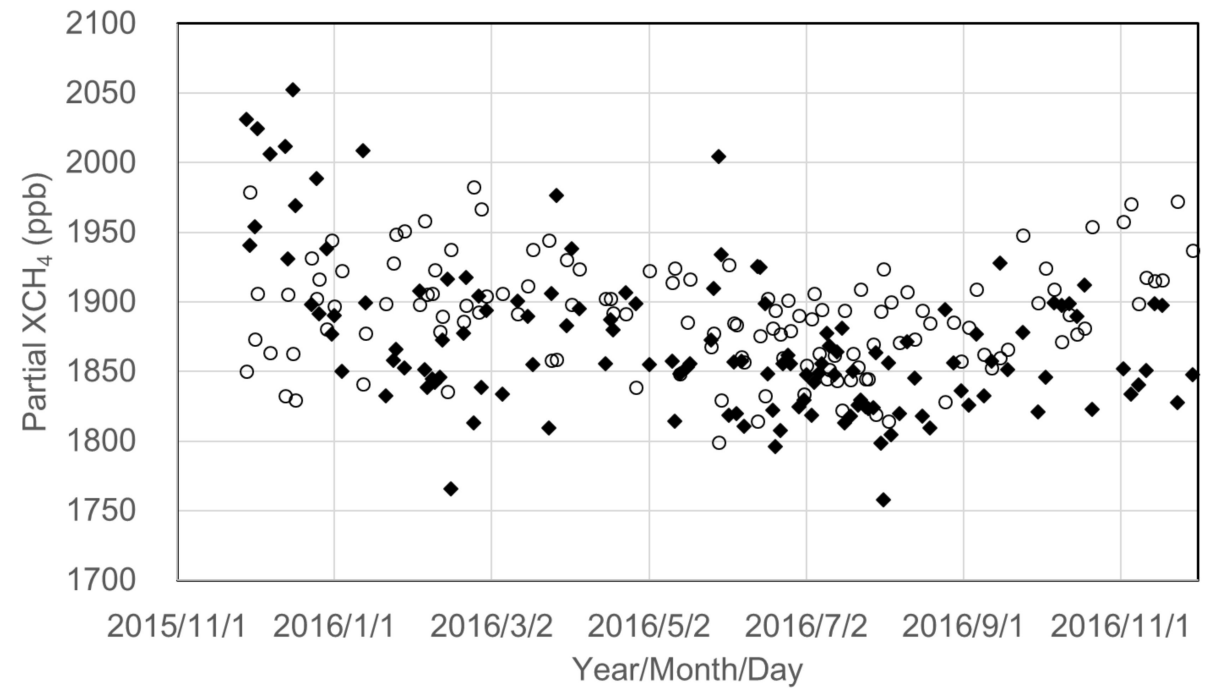

Figure 3. $\mathrm{CH}_{4}$ partial column-averaged dry-air mole fractions of the lower troposphere $\left(\mathrm{XCH}_{4}(\mathrm{LT})\right)$ (diamonds) and the upper troposphere $\left(\mathrm{XCH}_{4}(\mathrm{UT})\right)$ (circles) at Aliso Canyon-S.

As illustrated in Figure 1b, the leak point was located at the edge of Aliso Canyon-N and outside of Aliso Canyon-S. The $\mathrm{CH}_{4}$ plume should not have entered the GOSAT footprint from any direction between $90^{\circ}$ (east) and $315^{\circ}$. We rejected the data not meeting this criterion, based on Weather Research and Forecasting (WRF) model calculations [37]. We used simulated wind direction at the location of the leak point $\left(34.31^{\circ} \mathrm{N}, 118.56^{\circ} \mathrm{W}\right)$, height of $906.9 \mathrm{hPa}$, and time of 20:50 UTC. As a result, large fluctuations in data were removed. The selected data showed a large enhancement in November (just after the blowout), followed by a clear decrease. The outliers above the uncertainty level of $0.056 \mathrm{ppb} / \mathrm{ppm}$ of $\triangle \mathrm{XCH}_{4}(\mathrm{LT}) / \mathrm{XCO}_{2}(\mathrm{LT})$ were mostly removed, as shown in Figure 4 . The flat topography of Aliso Canyon-S allowed for more accurate monitoring capability in detecting the blowout and confirming blocking of the leak. Figure 4 presents some data that have negative values larger than the uncertainty level, probably due to $\mathrm{CH}_{4}$ inflow, which is not correlated with $\mathrm{CO}_{2}$ enhancement. Simi Valley is not an ideal upwind reference.

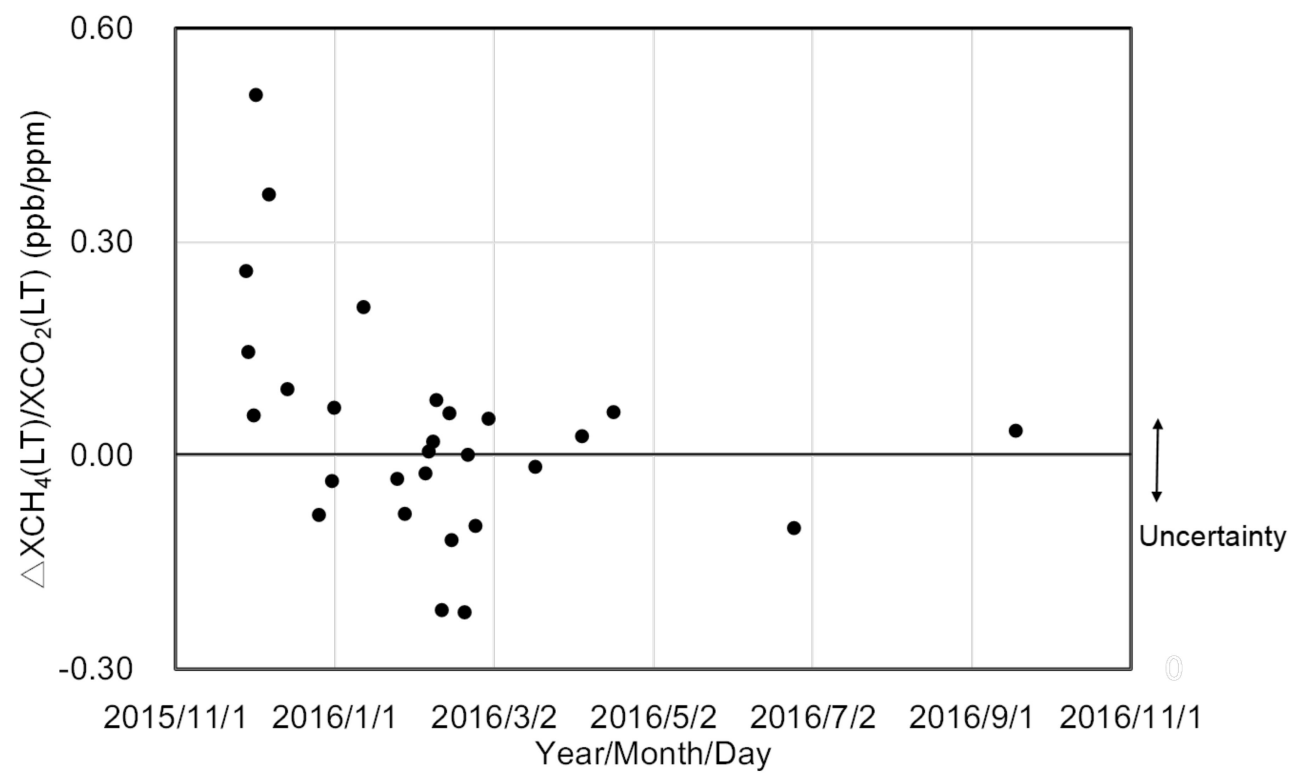

Figure 4. $\mathrm{XCH}_{4}$ (LT) enhancements with time normalized with $\mathrm{XCO}_{2}$ (LT) between the blowout and leak control. Data with wind direction of East-South-Northwest at the leak point were filtered out. 


\section{Reducing Uncertainties in the Local Flux Estimation}

There were four major causes of uncertainty in the case study for estimating the local flux from a point source using Equation (1): retrieval of $\mathrm{XCH}_{4}(\mathrm{LT}), \mathrm{V}, \mathrm{L}_{\mathrm{s}}$, and background removal.

(a) Satellite remote sensing has common retrieval errors in forward calculation, in addition to random instrument noise and radiometric calibration errors. Multiple scattering by aerosols and clouds, bidirectional reflection on Earth's surface, uncertainties in line parameters, and the solar model cause both bias and random errors. It is difficult to significantly reduce the current $\mathrm{XCH}_{4}$ retrieval uncertainty of $13 \mathrm{ppb}$. The GOSAT IFOV is too large, compared to the areas of the Aliso Canyon $\mathrm{CH}_{4}$ gas blowout. By improving spatial resolution to the scale of the emissions area, differential $\mathrm{XCH}_{4}$ (LT) measurements can be significantly enhanced, possibly enabling more accurate estimates of local $\mathrm{CH}_{4}$ emission.

(b) The number of sites where wind speed and direction are monitored regularly is limited. The data were available only at the Burbank Airport, which is $22 \mathrm{~km}$ away from the emissions source. In addition, their vertical profiles were not measured. Thus, we instead have to use a simulation such as the WRF model with large uncertainties. We need more validation data for the wind speed simulation in the boundary layer.

(c) In Aliso Canyon, the wind direction during the GOSAT overpass varied each day. The point of leakage was decentered for Aliso Canyon-N and outside the footprint for Aliso Canyon-S. Without accurate wind direction information, the flux cannot be estimated. Targeting the center of the emissions point can cover a plume in any wind direction. The present single-pixel GOSAT with its two-axis pointing system limits the number of observation points. Multi-pixel data will help in inferring the wind direction and in selecting proper reference points upwind for each flux estimate.

(d) A proper upwind reference closer to the emissions source assumed as a background can remove $\mathrm{CH}_{4}$ contamination from the surrounding area. Imaging capability and a smaller footprint with a flat topography would provide a more accurate background level than the current method using Simi Valley data. For example, $\mathrm{XCH}_{4}$ acquired by TROMOMI may be useful for this purpose [38]. A more robust algorithm for topography is also needed.

TANSO-FTS was designed to demonstrate accurate remote sensing from space with marginal spectral resolution using a single-pixel detector. FTS needs mechanical scan time to acquire the interferogram and the spectral resolution becomes worse when the off-axis angle becomes larger. Conventional space borne FTSs use near-optical axis areas: $1,2 \times 2$, and $3 \times 3$ pixels for GOSAT, IASI, and CrIS, respectively. A grating spectrometer with a two-dimensional detector can acquire multiple pixel data in the CT direction within an electrical integration time, which is much shorter than the mechanical scan time of the GOSAT FTS. We can allocate spectral information in one dimension and $\mathrm{CT}$ electrical scan for the other dimension. Aberration-corrected grating technology can widen the CT field of view. With satellite motion, we can acquire image data that have at least 1000 times more sampling points than the existing GOSAT. To achieve this, we propose an imaging capability with a $1 \mathrm{~km}^{2}$ spatial resolution to monitor plume orientation and simultaneous measurement of short-lived species to estimate the wind speed and direction [39].

\section{Conclusions}

In this paper, we present a case study on $\mathrm{CH}_{4}$ emissions from a natural gas leak at Aliso Canyon using target observations with a pointing mechanism. We used the time-series of the partial column-averaged dry-air mole fractions of the lower troposphere, $\mathrm{XCH}_{4}(\mathrm{LT})$, retrieved by simultaneous use of reflected solar light and thermal emission. Frequent and long-term satellite observations, with appropriate background references, can detect $\mathrm{CH}_{4}$ enhancements from local-point emission sources and even capture total emissions. $\mathrm{XCH}_{4}(\mathrm{LT})$ minimizes the effects of inflow of $\mathrm{CH}_{4}$ in the UT and the stratosphere. The $\mathrm{CH}_{4}$ blowout event at Aliso Canyon was clearly seen in the temporal changes in $\mathrm{XCH}_{4}$ (LT). Normalization with $\mathrm{XCO}_{2}$ (LT) reduced the effects of $\mathrm{CH}_{4}$ inflow to the target areas. Geometric mismatch between the emission point and the center of the GOSAT footprint needed 
screening using the WRF wind direction data. However, the large footprint made it difficult to enhance $\mathrm{XCH}_{4}$ (LT) further with more flat topography and estimate the flux variation quantitatively. Imaging capability and a higher spatial resolution with a two-dimensional multi-pixel detector may reduce uncertainties in the local flux estimation from point sources.

Author Contributions: A.K. contributed to satellite operation, data analyses, and preparation of the manuscript. N.K. and F.K. are responsible for partial-column density retrieval and WRF calculation, respectively. H.S., K.S., and Y.K. selected target observation points and reviewed the data analysis. All authors have read and agreed to the published version of the manuscript.

Funding: This research received no external funding.

Acknowledgments: The authors thank Kenji Kowata of the Remote Sensing Technology Center of Japan and Emma Yates and Laura Iraci of NASA Ames research center. The authors also wish to thank the GOSAT operation team, RemoTeC team, and ACOS team. The level $1 \mathrm{~B}$ radiance spectra data are available at GDAS. The GOSAT $\mathrm{XCH}_{4}$ data obtained in the target mode at the selected sites are available at http://www.eorc.jaxa.jp/GOSAT/CO2 monitor/index.html. European Commission: Emission Database for Global Atmospheric Research (EDGAR), release version 4.2, Tech. rep., Joint Research Centre (JRC)/Netherlands Environmental Assessment Agency (PBL), is available at: http://edgar.jrc.ec.europa.eu.

Conflicts of Interest: The authors declare no conflict of interest.

\section{Appendix A. Background Subtraction, Normalization, and Filtering Processes}

\section{Appendix A.1. Background Subtraction Using Reference Point Data}

Assuming the LT inflow is locally spatially constant, Equation (A1) calculates the enhancement from the point source using nearby reference data as follows:

$$
\Delta \mathrm{XCH}_{4}(\mathrm{LT})=\mathrm{XCH}_{4}(\mathrm{LT})_{\mathrm{s}}-\mathrm{XCH}_{4}(\mathrm{LT})_{\mathrm{r}}
$$

where $\mathrm{XCH}_{4}(\mathrm{LT})_{\mathrm{s}}$ and $\mathrm{XCH}_{4}(\mathrm{LT})_{\mathrm{r}}$ are $\mathrm{XCH}_{4}(\mathrm{LT})$ over the source and reference points measured by GOSAT within the same orbit path, respectively.

Figure A1 shows the $\mathrm{XCH}_{4}$ (LT) enhancement from Simi Valley at: (a) Aliso Canyon-S; and (b) Aliso Canyon-N and Burbank. Both Aliso Canyon-N and Aliso Canyon-S show enhancement in November and December 2015, and decrease with time in 2016. The enhancement in Burbank is less clear. Individual values show fluctuation and sometimes have negative values. Simi Valley, as a reference, is located close to the blowout point, but also close to urban areas. This is because the amount of inflow at Simi Valley was not the same for all the sites. 


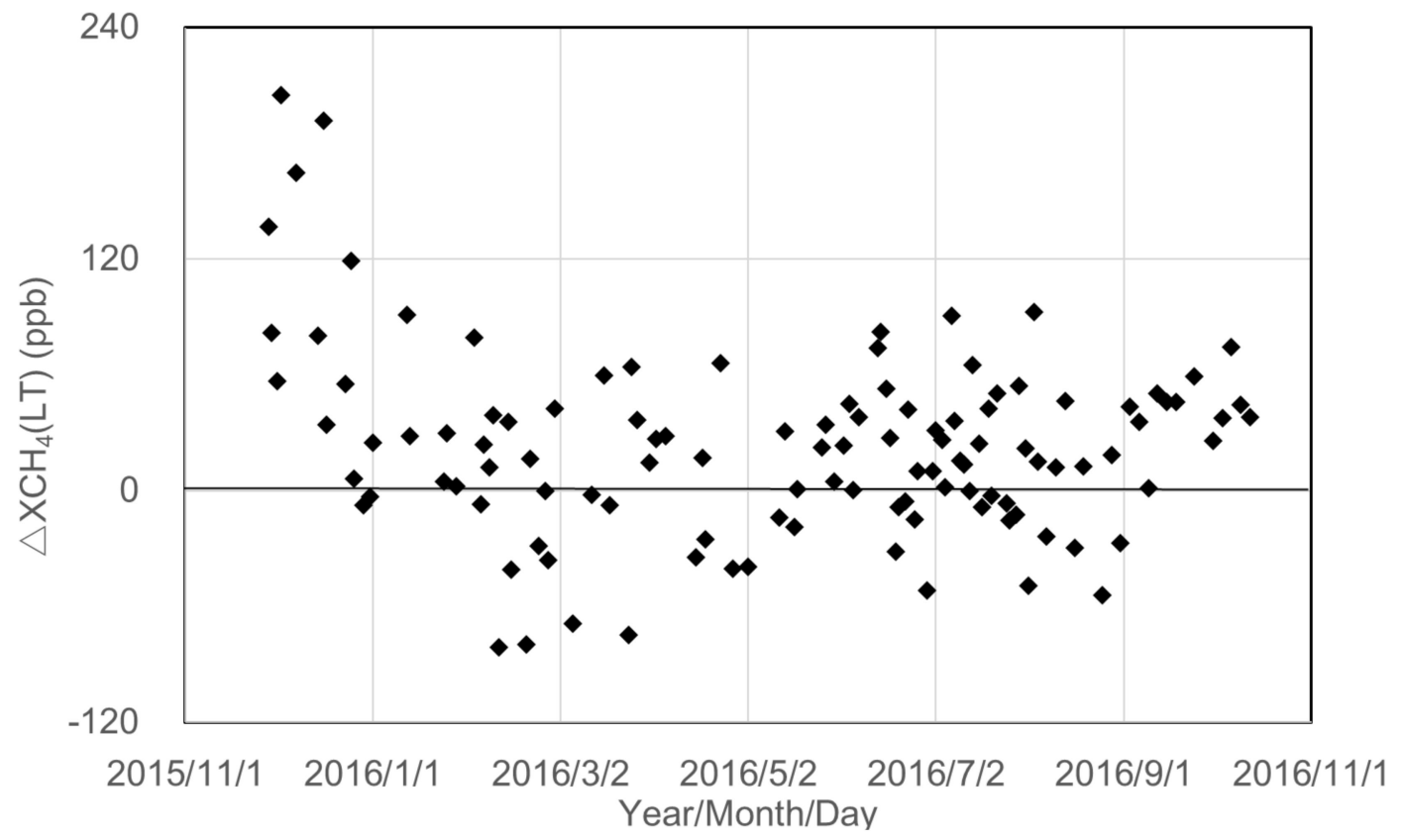

(a)

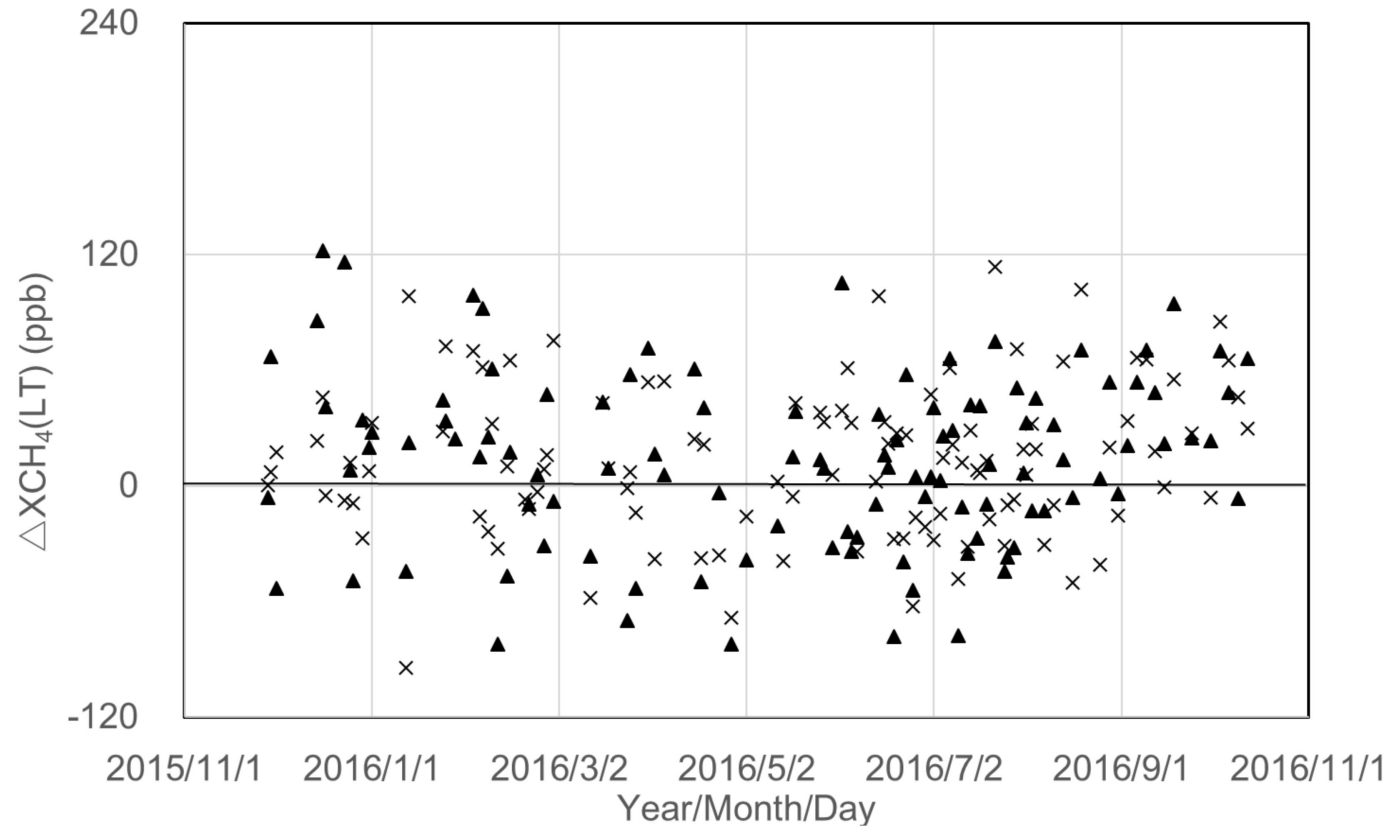

(b)

Figure A1. Time trend of successfully retrieved data: (a) $\mathrm{XCH}_{4}$ (LT) enhancement from Simi Valley data of Aliso Canyon-S (diamonds); and (b) the same as (a) except for Aliso Canyon-N (triangles) and Burbank (crosses).

Appendix A.2. Normalization Process

As there are other $\mathrm{CH}_{4}$ and large $\mathrm{CO}_{2}$ emission sources in Southern California, we introduced the $\mathrm{XCH}_{4}(\mathrm{LT}) / \mathrm{XCO}_{2}(\mathrm{LT})$ ratio to reduce contamination by temporal inflow, which is not equal to the source 
and reference. Assuming the common virtual background for source and sink, the enhancement trend of Aliso Canyon can be monitored as presented in Equation (A2).

$$
\begin{aligned}
& \Delta \frac{\mathrm{XCH}_{4}(\mathrm{LT})}{\mathrm{XCO}_{2}(\mathrm{LT})}=\frac{\mathrm{XCH}_{4}(\mathrm{LT})_{\mathrm{s}}}{\mathrm{XCO}_{2}(\mathrm{LT})_{\mathrm{s}}}-\frac{\mathrm{XCH}_{4}(\mathrm{LT})_{\mathrm{r}}}{\mathrm{XCO}_{2}(\mathrm{LT})_{\mathrm{r}}} \\
& =\frac{\mathrm{XCH}_{4}(\mathrm{LT})_{\mathrm{e}}+\mathrm{XCH}_{4}(\mathrm{LT})_{\mathrm{b}}+\mathrm{XCH} \mathrm{CH}_{4}(\mathrm{LT})_{\mathrm{si}}}{\mathrm{XCO}_{2}(\mathrm{LT})_{\mathrm{b}}+\mathrm{XCO}_{2}(\mathrm{LT})_{\mathrm{si}}}-\frac{\mathrm{XCH}_{4}(\mathrm{LT})_{\mathrm{b}}+\mathrm{XCH}_{4}(\mathrm{LT})_{\mathrm{ri}}}{\mathrm{XCO}_{2}(\mathrm{LT})_{\mathrm{b}}+\mathrm{XCO}_{2}(\mathrm{LT})_{\mathrm{ri}}} \\
& \cong \frac{\mathrm{XCH}{ }_{4}(\mathrm{LT})_{\mathrm{e}}}{\mathrm{XCO}_{2}(\mathrm{LT})_{\mathrm{b}}+\mathrm{XCO}_{2}(\mathrm{LT})_{\mathrm{si}}}
\end{aligned}
$$

The suffixes e, b, si, and ri denote enhancement by emissions from the source, background, and inflow at the source and reference points, respectively.

Aliso Canyon is surrounded by the Transverse Range and urban areas. There are both $\mathrm{CO}_{2}$ and $\mathrm{CH}_{4}$ emission sources in the urban areas; consequently, the inflow to Aliso Canyon has mixed contamination. Assuming that $\mathrm{XCH}_{4}(\mathrm{LT}) / \mathrm{XCO}_{2}(\mathrm{LT})$ of inflow to the source and reference from urban areas have common values, the above equation can extract enhancement from the $\mathrm{CH}_{4}$ point source. Figure A2 shows a reduction of $20 \mathrm{ppb}$ in the positive bias in the case of background $\mathrm{XCO}_{2}$ (LT) of $400 \mathrm{ppm}$. Considering the uncertainty of $13 \mathrm{ppb}$ in $\mathrm{XCH}_{4}(\mathrm{LT})$ and $2.1 \mathrm{ppm}$ in $\mathrm{XCO}_{2}$ (LT) in the source and reference points, and assuming that both are random, the uncertainty level in enhancement is $0.056 \mathrm{ppb} / \mathrm{ppm}$ (Figure 4). This approach is effective for removing uncertainty due to the inflow and monitoring the trend, but we require wind information for quantitative discussion.

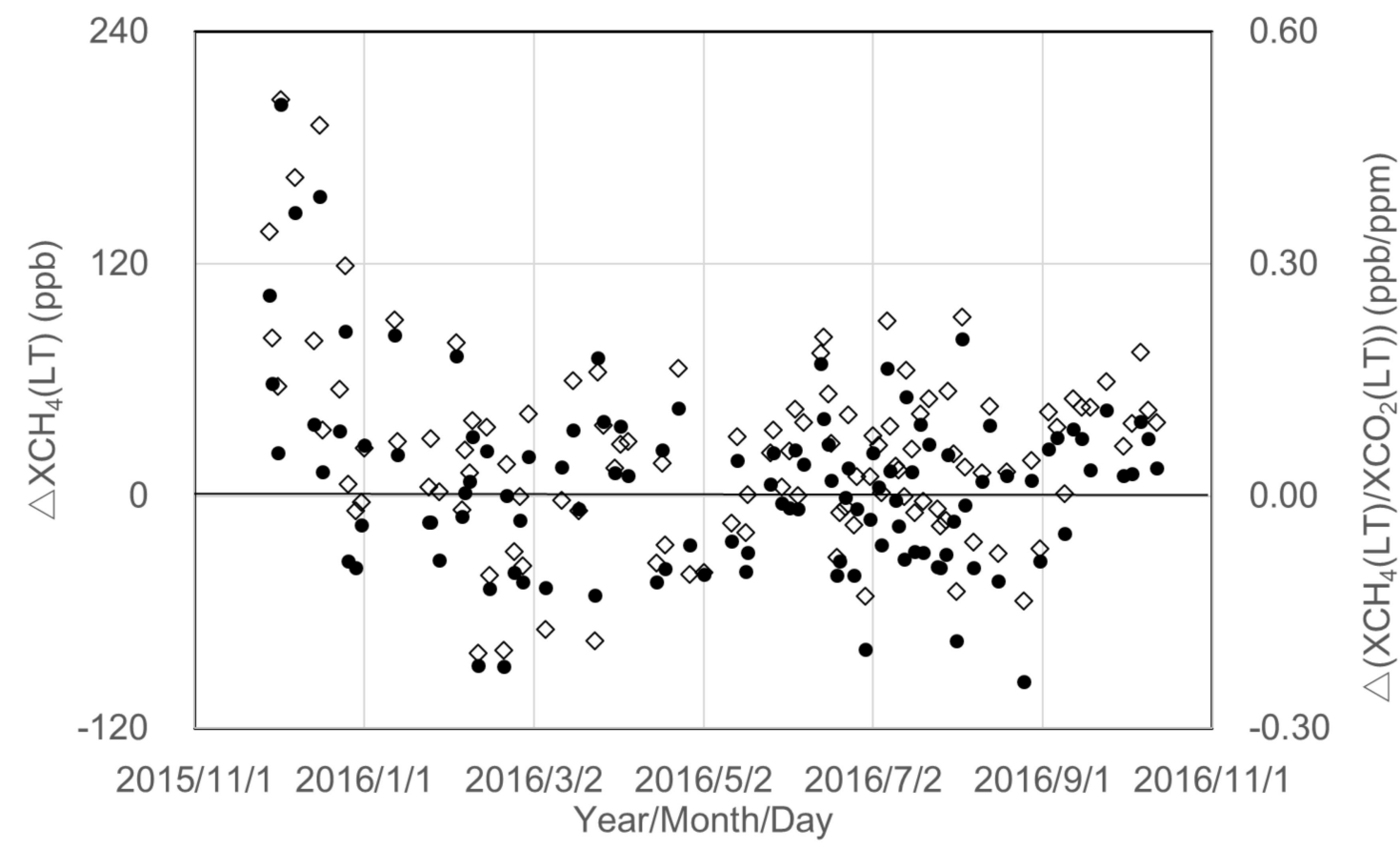

Figure A2. $\mathrm{XCH}_{4}(\mathrm{LT})$ enhancement from Simi Valley data (diamonds) and for $\mathrm{XCH}_{4}(\mathrm{LT}) / \mathrm{XCO}_{2}(\mathrm{LT})$ (circles).

\section{Appendix A.3. Filtering with Wind Direction}

The sites where wind speed and direction are monitored regularly are limited. The data were available only at Burbank Airport, which is $22 \mathrm{~km}$ from the emissions source. Thus, we instead used the WRF model to simulate the actual atmospheric conditions. Figure A3 shows the $\mathrm{XCH}_{4}(\mathrm{LT}) / \mathrm{XCO}_{2}(\mathrm{LT})$ ratio and the WRF wind direction at the leak point $\left(34.31^{\circ} \mathrm{N}, 118.56^{\circ} \mathrm{W}\right)$ during GOSAT overpass (20:50 UTC), at a height of $906.9 \mathrm{hPa}$. We filtered out data with a wind direction of East-South-Northwest (90-315 $)$ using the WRF wind direction. 


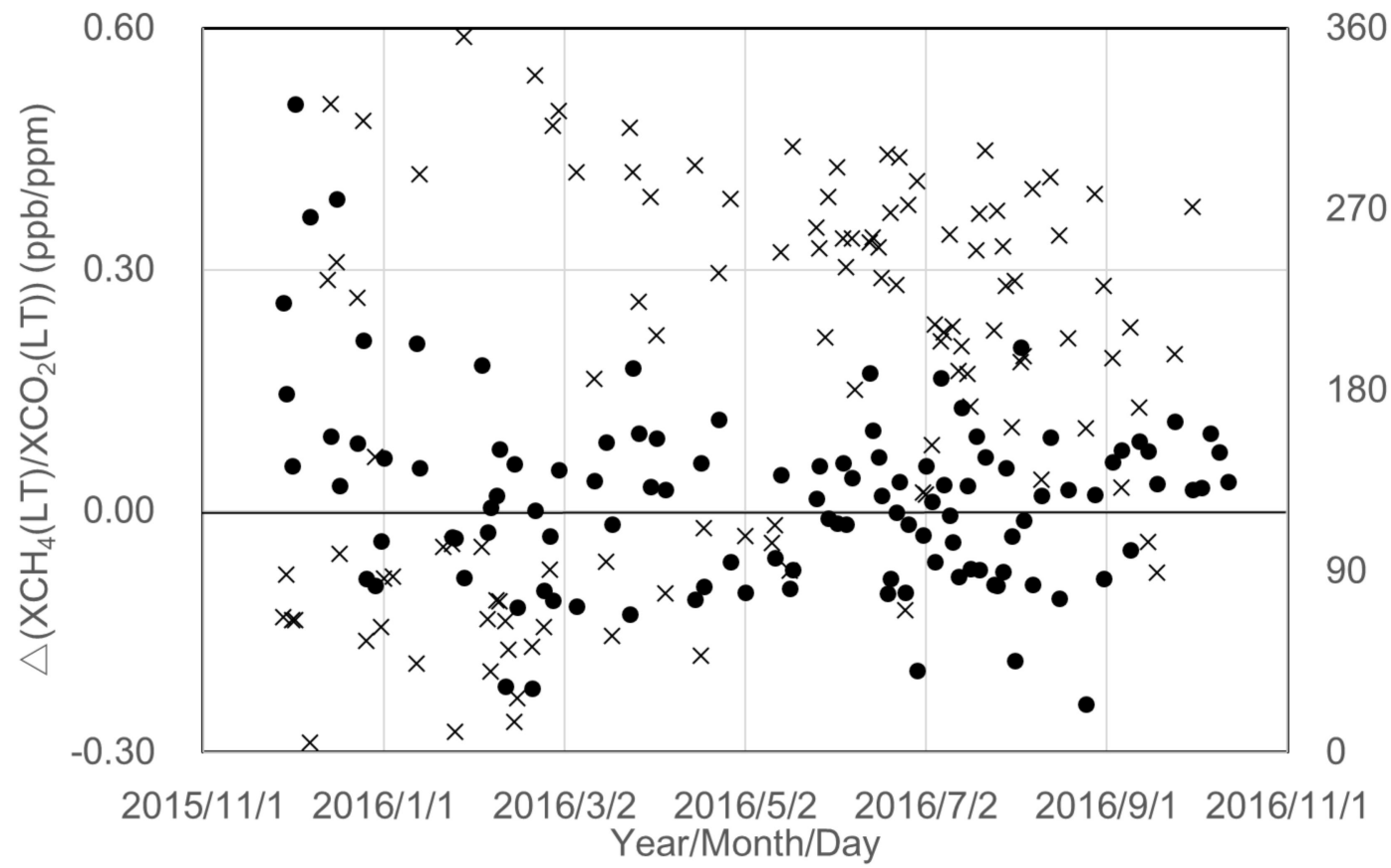

Figure A3. $\mathrm{XCH}_{4}(\mathrm{LT}) / \mathrm{XCO}_{2}(\mathrm{LT})$ enhancement with time between the blowout and leak control (circles) as well as the WRF wind direction (crosses).

\section{References}

1. Thompson, D.R.; Thorpe, A.K.; Frankenberg, C.; Green, R.O.; Duren, R.; Guanter, L.; Hollstein, A.; Middleton, E.; Ong, L.; Ungar, S. Space-based remote imaging spectroscopy of the Aliso Canyon $\mathrm{CH}_{4}$ superemitter. Geophys. Res. Lett. 2016, 43, 6571-6578. [CrossRef]

2. Frankenberg, C.; Thorpe, A.K.; Thompson, D.R.; Hulley, G.; Kort, E.A.; Vance, N.; Borchardt, J.; Krings, T.; Gerilowski, K.; Sweeney, C.; et al. Airborne methane remote measurements reveal heavy-tail flux distribution in Four Corners region. Proc. Natl. Acad. Sci. USA 2016, 113, 9734-9739. [CrossRef]

3. Duren, R.M.; Thorpe, A.K.; Foster, K.T.; Rafiq, T.; Hopkins, F.M.; Yadav, V.; Bue, B.D.; Thompson, D.R.; Conley, S.; Colombi, N.K.; et al. California's methane super-emitters. Nature 2019, 575, 180-184. [CrossRef] [PubMed]

4. Jacob, D.J.; Turner, A.J.; Maasakkers, J.D.; Sheng, J.; Sun, K.; Liu, X.; Chance, K.; Aben, I.; McKeever, J.; Frankenberg, C. Satellite observations of atmospheric methane and their value for quantifying methane emissions. Atmos. Chem. Phys. 2016, 16, 14371-14396. [CrossRef]

5. Buchwitz, M.; de Beek, R.; Burrows, J.P.; Bovensmann, H.; Warneke, T.; Notholt, J.; Meirink, J.F.; Goede, A.P.H.; Bergamaschi, P.; Körner, S.; et al. Atmospheric methane and carbon dioxide from SCIAMACHY satellite data: Initial comparison with chemistry and transport models. Atmos. Chem. Phys. 2005, 5, 941-962. [CrossRef]

6. Crisp, D.; Atlas, R.M.; Bréon, F.-M.; Brown, L.R.; Burrows, J.P.; Ciais, P.; Connor, B.J.; Doney, S.C.; Fung, I.Y.; Jacob, D.J.; et al. The Orbiting Carbon Observatory (OCO) mission. Adv. Space Res. 2004, 34, 700-709. [CrossRef]

7. Yang, D.X.; Liu, Y.; Cai, Z.N.; Chen, X.; Yao, L.; Lu, D.R. First global carbon dioxide maps produced from TanSat measurements. Adv. Atmos. Sci. 2018, 35, 621-623. [CrossRef]

8. Varon, D.J.; McKeever, J.; Jervis, D.; Maasakkers, J.D.; Pandey, S.; Houweling, I.; Aben, I.; Scarpelli, T.; Jacob, D.J. Satellite discovery of anomalously large methane point sources from oil/gas production. Geophys. Res. Lett. 2019, 46, 13507-13516. [CrossRef]

9. Veefkind, J.; Aben, I.; McMullan, K.; Förster, H.; de Vries, J.; Otter, G.; Claas, J.; Eskes, H.; de Haan, J.; Kleipool, Q.; et al. TROPOMI on the ESA Sentinel-5 precursor: A GMES mission for global observations of the atmospheric composition for climate, air quality and ozone layer applications, the Sentinel missions-New opportunities for science. Remote Sens. Environ. 2012, 120, 70-83. [CrossRef] 
10. Eldering, A.; Kaki, S.; Crisp, D.; Gunson, M.R. The OCO-3 Mission; The American Geophysical Union Fall Meeting: San Francisco, CA, USA, 2013.

11. Kuze, A.; Suto, H.; Nakajima, M.; Hamazaki, T. Thermal and near infrared sensor for carbon observation Fourier-transform spectrometer on the Greenhouse Gases Observing Satellite for greenhouse gases monitoring. Appl. Opt. 2009, 48, 6716-6733. [CrossRef]

12. Kuze, A.; Suto, H.; Shiomi, K.; Kawakami, S.; Tanaka, M.; Ueda, Y.; Deguchi, A.; Yoshida, J.; Yamamoto, Y.; Kataoka, F.; et al. Update on GOSAT TANSO-FTS performance, operations, and data products after more than 6 years in space. Atmos. Meas. Tech. 2016, 9, 2445-2461. [CrossRef]

13. Maddy, E.S.; Barnet, C.D.; Goldberg, M.; Sweeney, C.; Liu, X. $\mathrm{CO}_{2}$ retrievals from the Atmospheric Infrared Sounder: Methodology and validation. J. Geophys. Res. 2008, 113, D11301. [CrossRef]

14. Beer, R.; Glavich, T.A.; Rider, D.M. Tropospheric emission spectrometer for the Earth Observing System's Aura Satellite. Appl. Opt. 2001, 40, 2356-2367. [CrossRef] [PubMed]

15. Clerbaux, C.; Boynard, A.; Clarisse, L.; George, M.; Hadji-Lazaro, J.; Herbin, H.; Hurtmans, D.; Pommier, M.; Razavi, A.; Turquety, S.; et al. Monitoring of atmospheric composition using the thermal infrared IASI/MetOp sounder. Atmos. Chem. Phys. 2009, 9, 6041-6054. [CrossRef]

16. Tobin, D.; Tobin, D.; Revercomb, H.; Knuteson, R.; Taylor, J.; Best, F.; Borg, L.; DeSlover, D.; Martin, G.; Buijs, H.; et al. Suomi-NPP CrIS radiometric calibration uncertainty. J. Geophys. Res. Atmos. 2013, 118, 10589-10600. [CrossRef]

17. Turner, A.J.; Jacob, D.J.; Wecht, K.J.; Maasakkers, J.D.; Biraud, S.C.; Boesch, H.; Bowman, K.W.; Deutscher, N.M.; Dubey, M.K.T.; Griffith, D.W.; et al. Estimating global and North American methane emissions with high spatial resolution using GOSAT satellite data. Atmos. Chem. Phys. 2015, 15, 7049-7069. [CrossRef]

18. Sheng, J.-X.; Jacob, D.J.; Turner, A.J.; Maasakkers, J.D.; Benmergui, J.; Bloom, A.A.; Arndt, C.; Gautam, R.; Zavala-Araiza, D.; Boesch, H.; et al. 2010-2016 methane trends over Canada, the United States, and Mexico observed by the GOSAT satellite: Contributions from different source sectors. Atmos. Chem. Phys. 2018, 18, 12257-12267. [CrossRef]

19. Wunch, D.; Toon, G.C.; Blavier, J.-F.L.; Washenfelder, R.A.; Notholt, J.; Connor, B.J.; Griffith, D.W.T.; Sherlock, V.; Wennberg, P.O. The Total Carbon Column Observing Network. Philos. Trans. R. Soc. A 2011, 369, 2087-2112. [CrossRef]

20. Butz, A.; Guerlet, S.; Hasekamp, O.; Schepers, D.; Galli, A.; Aben, I.; Frankenberg, C.; Hartmann, J.-M.; Tran, H.; Kuze, A.; et al. Toward accurate $\mathrm{CO}_{2}$ and $\mathrm{CH}_{4}$ observations from GOSAT. Geophys. Res. Lett. 2011, 38, L14812. [CrossRef]

21. Guerlet, S.; Butz, A.; Schepers, D.; Basu, S.; Hasekamp, O.P.; Kuze, A.; Yokota, T.; Blavier, J.-F.; Deutscher, N.M.; Griffith, D.W.T.; et al. Impact of aerosol and thin cirrus on retrieving and validating $\mathrm{XCO}_{2}$ from GOSAT shortwave infrared measurements. J. Geophys. Res. Atmos. 2013, 118, 4887-4905. [CrossRef]

22. Schepers, D.; Guerlet, S.; Butz, A.; Landgraf, J.; Frankenberg, C.; Hasekamp, O.; Blavier, J.F.; Deutscher, N.M.; Griffith, D.W.T.; Hase, F.; et al. Methane retrievals from Greenhouse Gases Observing Satellite (GOSAT) shortwave infrared measurements: Performance comparison of proxy and physics retrieval algorithms. J. Geophys. Res. 2012, 117, D10307. [CrossRef]

23. Crisp, D.; Fischer, B.M.; O’Dell, C.; Frankenberg, C.; Basilio, R.; Bösch, H.; Brown, L.R.; Castano, R.; Connor, B.; Deutscher, N.M.; et al. The ACOS $\mathrm{XCO}_{2}$ retrieval algorithm, Part II: Global $\mathrm{XCO}_{2}$ data characterization. Atmos. Meas. Tech. 2012, 5, 1-21. [CrossRef]

24. Yoshida, Y.; Kikuchi, N.; Morino, I.; Uchino, O.; Oshchepkov, S.; Bril, A.; Saeki, T.; Schutgens, N.; Toon, G.C.; Wunch, D.M.; et al. Improvement of the retrieval algorithm for GOSAT SWIR $\mathrm{XCO}_{2}$ and $\mathrm{XCH}_{4}$ and their validation using TCCON data. Atmos. Meas. Tech. 2013, 6, 1533-1547. [CrossRef]

25. Parker, R.; Boesch, H.; Cogan, A.; Fraser, A.; Feng, L.; Palmer, P.I.; Messerschmidt, J.; Deutscher, N.; Griffith, D.W.T.; Notholt, J.; et al. Methane observations from the Greenhouse Gases Observing SATellite: Comparison to ground-based TCCON data and model calculations. Geophys. Res. Lett. 2011, 38, L15807. [CrossRef]

26. Saitoh, N.; Kimoto, S.; Sugimura, R.; Imasu, R.; Kawakami, S.; Shiomi, K.; Kuze, A.; Machida, T.; Sawa, Y.; Matsueda, $\mathrm{H}$. Algorithm update of the GOSAT/TANSO-FTS thermal infrared $\mathrm{CO}_{2}$ product (version 1) and validation of the UTLS $\mathrm{CO}_{2}$ data using CONTRAIL measurements. Atmos. Meas. Tech. 2016, 9, 2119-2134. [CrossRef] 
27. Kikuchi, N.; Yoshida, Y.; Uchino, O.; Morino, I.; Yokota, T. An advanced retrieval algorithm for greenhouse gases using polarization information measured by GOSAT TANSO-FTS SWIR I: Simulation study. J. Geophys. Res. Atmos. 2016, 121. [CrossRef]

28. Kikuchi, N.; Kuze, A.; Kataoka, F.; Shiomi, K.; Hashimoto, M.; Suto, H.; Knuteson, R.; Iraci, L.; Yates, E.; Gore, W.; et al. Three-Dimensional Distribution of Greenhouse Gas Concentrations over Megacities Observed by GOSAT; The American Geophysical Union Fall Meeting: San Francisco, CA, USA, 2017.

29. Yates, E.L.; Lowenstein, M.; Iraci, L.T.; Tadic, J.; Sheffner, E.J.; Schiro, K.; Kuze, A. Carbon dioxide and methane at a desert site-A case study at Railroad Valley playa, Nevada, USA. MDPI Atmos. 2011, 2, 702-714. [CrossRef]

30. Tadic, J.M.; Lowenstein, M.; Frankenberg, C.; Butz, A.; Roby, M.; Iraci, L.T.; Yates, E.L.; Gore, W.; Kuze, A. A comparison of in-situ aircraft measurements of carbon dioxide and methane to GOSAT data measured over Railroad Valley playa, Nevada, USA. IEEE Trans. Geosci. Remote Sens. 2014, 52, 7764-7774. [CrossRef]

31. Tanaka, T.; Yates, E.; Iraci, L.; Johnson, M.S.; Gore, W.; Tadic, J.M.; Loewenstein, M.; Kuze, A.; Frankenberg, C.; Butz, A.; et al. Two year comparison of airborne measurements of $\mathrm{CO}_{2}$ and $\mathrm{CH}_{4}$ with GOSAT at Railroad Valley, Nevada. IEEE Trans. Geosci. Remote Sens. 2016, 54, 4367-4375. [CrossRef]

32. Iraci, L.T.; Yates, E.L.; Parworth, C.; Kuze, A.; Kikuchi, N.; Kataoka, F.; Shiomi, K.; Suto, H.; Kulawik, S.S.; Basu, S. Vertical Profiles of Greenhouse Gases Collected over Land and Water in the Western US in Support of Partial Column Validation Efforts; A43R-3147; AGU Fall Meeting: San Francisco, CA, USA, 2019.

33. Kataoka, F.; Knuteson, R.O.; Kuze, A.; Shiomi, K.; Suto, H.; Yoshida, J.; Kondo, S.; Saitoh, N. Calibration, Level 1 Processing and Radiometric Validation for TANSO-FTS TIR on GOSAT. IEEE Trans. Geosci. Remote Sens. 2019, 57, 3490-3500. [CrossRef]

34. Bedford, B. Free flight time for projects in atmospheric sciences. EOS Earth Space Sci. News 2018, 99. [CrossRef]

35. Conley, S.; Franco, G.; Faloona, I.; Blake, D.R.; Peischl, J.; Ryerson, T.B. Methane emissions from the 2015 Aliso Canyon blowout in Los Angeles, CA. Science 2016, 351, 1317-1320. [CrossRef] [PubMed]

36. Weather Underground. Available online: https://www.wunderground.com/ (accessed on 30 December 2019).

37. Skamarock, W.C.; Klemp, J.B.; Dudhia, J.; Gill, D.O.; Barker, D.M.; Duda, M.G.; Huang, X.-Y.; Wang, W.; Powers, J.G. A description of the advanced research WRF Version 3. NCAR Tech. Note NCAR/TN-475+STR 2008, 113. [CrossRef]

38. Hu, H.; Landgraf, J.; Detmers, R.; Borsdorff, T.; Aan de Brugh, J.; Aben, I.; Butz, A.; Hasekamp, O. Toward global mapping of methane with TROPOMI: First results and intersatellite comparison to GOSAT. Geophys. Res. Lett. 2018, 45. [CrossRef]

39. Kuze, A.; Suto, H. Imaging Spectrometer with an Agile Pointing System to Quantify Global and Regional Greenhouse Gas Fluxes and Monitor Localized Emission Sources. Trans. JSASS Aerosp. Tech. Jpn. 2018, 16, 147-151. [CrossRef]

(C) 2020 by the authors. Licensee MDPI, Basel, Switzerland. This article is an open access article distributed under the terms and conditions of the Creative Commons Attribution (CC BY) license (http://creativecommons.org/licenses/by/4.0/). 